\title{
鉄系軟磁性材料における磁化曲線の圧縮応力依存性
}

\author{
イジュラル ハシフ ${ }^{1, * 1}$ 島 田 宗 勝 ${ }^{2}$ 久保田 健 ${ }^{2, * 2}$ \\ 1弘前大学大学院理工学研究科 \\ 2弘前大学北日本新エネルギー研究所
}

J. Japan Inst. Met. Mater. Vol. 83, No. 1 (2019), pp. 1-8

(C) 2018 The Japan Institute of Metals and Materials

\section{Compression Dependence of Magnetization Curves on Iron-Based Soft Magnetic Materials}

Ijlal Hasif ${ }^{1, * 1}$, Munekatsu Shimada ${ }^{2}$ and Takeshi Kubota ${ }^{2, * 2}$

${ }^{1}$ Graduate School of Science and Technology, Hirosaki University, Hirosaki 036-8561

${ }^{2}$ North Japan Research Institute for Sustainable Energy, Hirosaki University, Aomori 030-0813

Magnetic properties of soft magnetic materials under stress are important, however, they have not fully understood. We measured magnetization curves of soft magnetic alloy sheets, electrical steel sheets and nanocrystalline alloys, with positive magnetostriction, under compression. The stress was applied in the same direction of magnetic fields. Magnetization curves have smaller slopes due to anisotropy of magnetoelasticity. The anisotropy energy was estimated from the magnetization curve. And we could obtain a stress dependence of the anisotropy energy; a relation between anisotropy energy and stress was a straight line. The slope of the line correlates magnetostriction values.

We devised a magnetic domain model under compression; a magnetization process on the model is a 90 degree magnetic domain wall movement; the relation between anisotropy energy and stress could be formulated. The magnetostriction values estimated from the line slope coincided with experimental ones. Therefore, it can be thought that the magnetization process under compression is mainly 90 degree domain wall movements. [doi:10.2320/jinstmet.J2018037]

(Received August 8, 2018; Accepted September 25, 2018; Published November 9, 2018)

Keywords: magnetization process, soft magnetic materials, anisotropy energy, magnetization curve, compression, stress, magnetostriction, magnetoelasticity, magnetic domain, magnetic domain wall, electrical steel sheets, nanocrystalline alloys

\section{1. 緒言}

モータ等の電磁機器における鉄心(軟磁性材料)には主に電 磁鋼板が用いられ，それらは応力下で使用されている。ま た, 軟磁性材料の磁気特性は応力に対して敏感である. 特に 圧縮応力下では磁化率が小さくなり, 鉄損が増加することが 知られている. 高効率な電磁機器設計においては, 応力下で の軟磁性材料の磁気特性に関するデータおよび知見が必要と されるため, 多くの検討がなされてきている ${ }^{1-5)}$. 磁化過程 の理解を進展させるための応力下での磁区観察も試みられて いる ${ }^{6,7)}$. しかしながら, 十分な理解には至っていない状況 にある、

そこで, 本研究では磁化過程に関する理解を深めることを 目的に, 応力下での磁化曲線を測定し解析することを試み た. 電磁鋼板と近年鋭意開発が進められている鉄系ナノ結晶 軟磁性材料を対象とした．前者については 1 世紀にわたる基 幹産業における実績により膨大な知見の集積があり, 磁化過 程もよく知られている材料である．特に方向性電磁鋼板は単 結晶に近い材料であるため磁化過程の理解がしやすい。一

\footnotetext{
*1 弘前大学大学院生 (Graduate Student, Hirosaki University)

*2 弘前大学地域戦略研究所 (Institute of Regional Innovation, Hirosaki University)
}

方, 後者は実質的な結晶磁気異方性がなく, 均質で等方的な 材料とみなせ, かつ優れた軟磁気特性であるため, 磁化過程 の研究には好適であろうと考え選択した。

測定は圧縮応力下での単純な磁区モデルが適用できるよう な条件で実施し，一様な応力下での磁化曲線を得た。また， 磁歪も同時に測定できるようにした．正の磁歪を有する軟磁 性材料に圧縮応力を印加すると, 磁化曲線は磁気弾性による 一軸異方性により，その傾きを小さくする．引張応力におけ る磁化曲線の変化は顕著でないため, 本論文では圧縮応力の 場合のみを論議の対象としている。 そのため応力值を+で表 示している. 応力下での磁化過程におけるエネルギーを磁化 曲線から求める方法を導出し, そのエネルギーの応力依存性 を得た．圧縮応力下における磁区モデルを想定し，90磁壁 移動が磁化過程であるとして, その磁化過程におけるエネル ギーの応力依存性を定式化した。応力依存性の傾きから求ま る磁歪の值は, 実測した磁歪の值とほぼ一致していた。 その ことから, 鉄系軟磁性材料における圧縮応力下での磁化過程 は $90^{\circ}$ 磁壁移動であると考えてよいという結果を得た。ま た, 応力下での磁歪の挙動も直線的であり, 磁壁移動を支持 している．なお，本論文では可逆磁化曲線，すなわち幅を持 たない(ヒステリシス損がない)とした磁化曲線における磁化 率の圧縮応力依存に関して議論している. 軟磁性材料の磁化 曲線における幅は良く知られているように小さい. 鉄損(ヒ ステリシス損)の圧縮および引張応力依存については別報に 
て議論している ${ }^{8)}$.

\section{2. 実 験 方 法}

\section{1 磁化曲線および磁歪の測定方法}

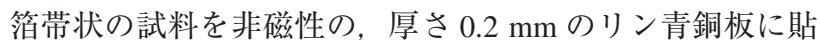
り付け, 曲げることにより一様な応力下での磁化曲線を得 た．板の表面に貼られていることから，Fig. 1 に示すよう に, 試料にはほぼ一様な応力が印加される。 3 点曲げにて曲 げ，曲げを加えた状態を維持しながら磁化曲線を測定した。 磁化曲線の測定には振動試料型磁力計 (Vibrating Sample Magnetometer; VSM)を用いた．試料の表面に歪ゲージを貼り， 歪により印加応力をモニターした，試料のヤング率を方向性 電磁鋼板 ${ }^{9}$ お よび $\mathrm{Fe}$ 系アモルファス合金 ${ }^{10)}$ の文献值を参照 し $200 \mathrm{GPa}$ として, 歪を応力に換算した，磁場印加方向，応 力印加方向は馢帯試料のロール方向とした．また，歪ゲージ も同方向に貼付した．印加する応力の大きさは $200 \mathrm{MPa}$ 未 满とし, 弾性域内に留めた。

試料の磁歪の值は, 応力ゼロの状態でゲージと同じ方向に 磁場印加した際の縦磁歪と, ゲージと直交する方向に磁場印 加した場合の横磁歪の飽和値をそれぞれ測定し両者の差であ るとして求めた，それを $3 / 2 \times \lambda_{s(m e)}$ とする。ここに $\lambda_{s(m e)}$ は 飽和磁歪定数である. なお，係数 $3 / 2$ は消磁状態を伸びの基 準にとって $\lambda$ を定義していることによって生じた係数であ $ろ^{11)}$.

また，本研究で用いた，試料は薄い，そのため磁歪の測定 には歪ゲージによる拘束，リン青銅板による拘束の影響があ る ${ }^{12)}$ 。そこで積層した試料の磁歪についても検討した。

また, 応力下での縦磁歪も測定した. その磁歪測定は磁化 測定と同時に行った。 なお, 磁歪測定結果には VSM 振動の 有無による変化はなかった.

\section{2 電磁鋼板とナノ結晶材料}

方向性, 無方向性電磁鋼板 (Si 3 mass \%) は日金電磁工業株 式会社製の極薄珪素鋼帯, GT050, ST050である。厚さは 50 $\mu \mathrm{m}$ であった．熱処理済みの製品より試料形状 $5 \mathrm{~mm} \times 10 \mathrm{~mm}$ (長手方向がロール方向)に切り出して用いた. 以下 GT, ST と記載する。なお，材料および試料の識別のため以下， GT-

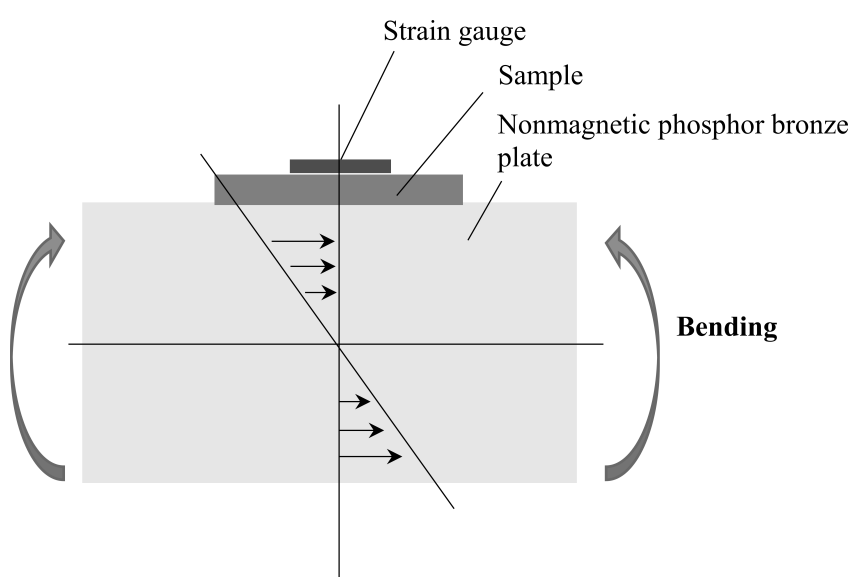

Fig. 1 Ribbon sample and stress application method. a, ST-b 等とする. 結晶組織の特徴は以下である，方向性電 磁鋼板では結晶粒方位(容易磁化方向)がロール方向に揃って いる。一方，無方向性電磁鋼板では結晶粒方位はランダムと なっている. 飽和磁化の值は $2.03 \mathrm{~T}^{13)}$ として磁化曲線の縦 軸を校正した。

ナノ結晶材料は $\mathrm{Fe}_{83.3} \mathrm{Si}_{5} \mathrm{~B}_{7} \mathrm{P}_{4} \mathrm{Cu}_{0.7}, \quad \mathrm{Fe}_{83.3} \mathrm{Si}_{6} \mathrm{~B}_{6} \mathrm{P}_{4} \mathrm{Cu}_{0.7}$ なる 組成の高飽和磁化材料であり, 厚さは $18 \mu \mathrm{m}$, 幅は $10 \mathrm{~mm}$ であった，それぞれの組成での最適熱処理を施してから, 試 料長さ $10 \mathrm{~mm}$ に切り出した. 以下, 前者を Fe574, Fe664 と 記載する. $\mathrm{Fe}_{83.3} \mathrm{Si}_{4} \mathrm{~B}_{8} \mathrm{P}_{4} \mathrm{Cu}_{0.7}$ が同系の最適な磁気特性を示す 組成である ${ }^{13)}$ が, 本研究では, 実験結果がわかりやすくな ることを期待し，磁歪の值が大きい，あえて少しずらした組 成を用いた，磁歪が大きいと磁化率は小さくなり，保磁力は 大きくなるため，磁歪を如何に減らすかが材料設計の目安と なっている. 本高飽和磁化ナノ結晶材料は 10〜20 nm 粒径 のナノ結晶粒と僅かな粒界残留アモルファス層を含む均質な 組織となっている ${ }^{13)}$. Fe574, Fe664 の飽和磁化はそれぞれ $1.77 \mathrm{~T}, 1.75 \mathrm{~T}$ であった。ナノ結晶材料では実質的に結晶磁 気異方性が消失していて, 優れた軟磁気特性を示し, 磁気的 に等方的で材料としても均質とみなせる，それゆえに，大き な磁区も観察されている ${ }^{14)}$.

\section{3 試料の磁歪について}

測定される試料の磁歪の值について補足する. 横向きに飽 和磁化した状態，すなわち横向きに単磁区となった状態を基 準として, 縦向きに飽和磁化した状態, すなわち縦向きに単 磁区となった状態の伸び(歪)を測定している，方向性電磁鋼 板に扔いては, 結晶粒が大きくからロール方向に配向してい ることから, 測定された磁歪の值は $3 / 2 \times \lambda_{100}$ と見なしてょ いと考えられる。ここで $\lambda_{100}$ とは 100 方向の磁歪定数であ る. さて, ここで結晶磁気異方性について議論しておく必要 がある. 3 mass\% Si の電磁鋼板の場合には結晶磁気異方性 定数 $K_{1}$ は $30 \mathrm{~kJ} / \mathrm{m}^{3}$ 程度 ${ }^{15)}$ と大きい. したがって磁化は容易 磁化方向である 100 方向を向いている，方向性電磁鋼板の場 合には，ロール方向が100 方向となっている，关れゆえ測定 された磁歪が $3 / 2 \times \lambda_{100}$ と見なせるのである. 一方，無方向 性電磁鋼板の場合には, 結晶粒方位はランダムであるから測 定された磁歪の值には $\lambda_{111}$ の影響が現れて，方向性よりも 小さくなるものと考えられる. 111 方向の磁歪定数 $\lambda_{111}$ は負 であるためである ${ }^{16)}$ 。また，ナノ結晶の場合には結晶磁気 異方性は消失しているので結晶の影響はなく, 等方的な磁歪 になっていると考えられる.

\section{3. 実験結果と考察}

\section{1 磁化曲線}

ナノ結晶材料の磁化曲線のフルループの例を Fig. 2 に示 す，横軸は外部磁場であり，反磁場補正を行っていないため 磁化曲線の傾きは小さくなっている，印加する圧縮応力が大 きくなるのに伴い磁化曲線の傾きは更に小さくなっている. 本研究では磁化曲線の相対的な傾きを比較し議論するため, 反磁場補正は不要である. Fig. $3 \sim 5$ に, ナノ結晶材料, 電 


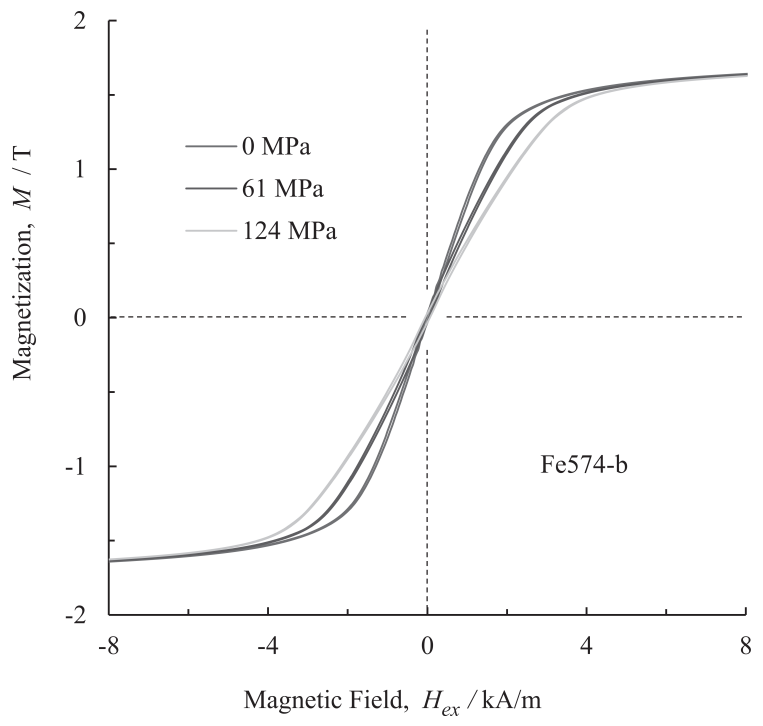

Fig. 2 Magnetization full loops of nanocrystalline alloy under compression.

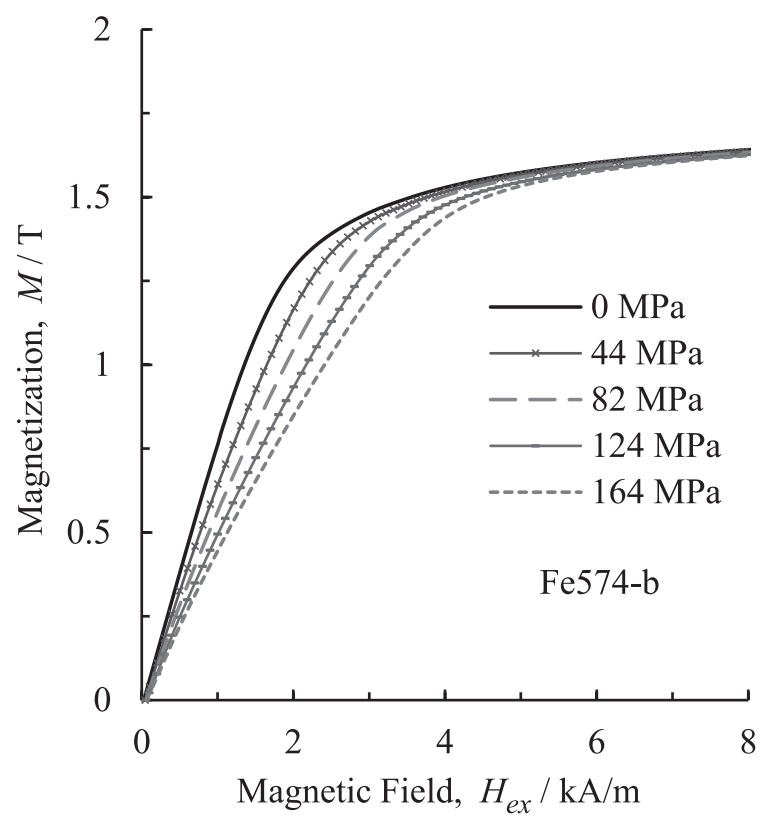

Fig. 3 Magnetization curves of nanocrystalline alloy under compression.

磁鋼板の立ち上がり磁化曲線の応力依存性を示す．どの材料 でも同様な傾向となっている.

\section{2 一軸異方性と磁化曲線からのエネルギー評価}

磁区の伸び(磁歪)を $3 / 2 \times \lambda_{s}$ とすると, 一軸異方性エネル ギーの大きさ $K_{u}$ は式 $(1)$ となる ${ }^{17,18)}$.

$$
K_{u}=\frac{3}{2} \lambda_{\mathrm{s}} \sigma
$$

ここに $\sigma$ は応力の大きさ， $\lambda_{s}$ は飽和磁歪定数である. 磁歪 が正の場合には，一軸異方性の方向は圧縮応力方向に対して 垂直である。磁区は圧縮応力に対して垂直，すなわち磁化方 向が横を向いた磁区の場合に最もエネルギーが低くなる。

磁化曲線の傾きは前述したように圧縮応力の大きさが増す につれて小さくなる。応力が増えた分だけ一軸異方性エネル

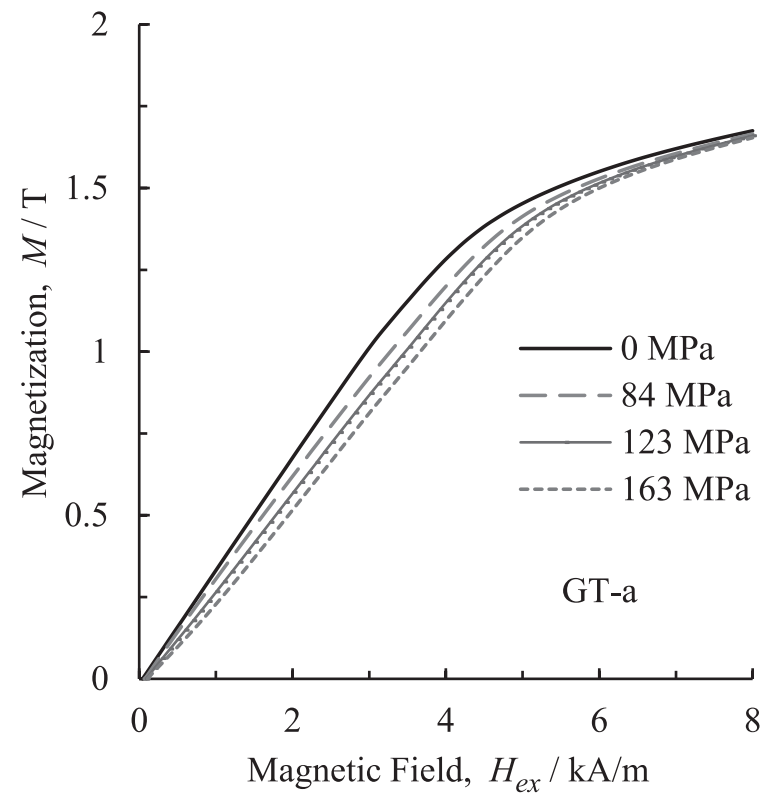

Fig. 4 Magnetization curves of oriented electrical steel sheet under compression.

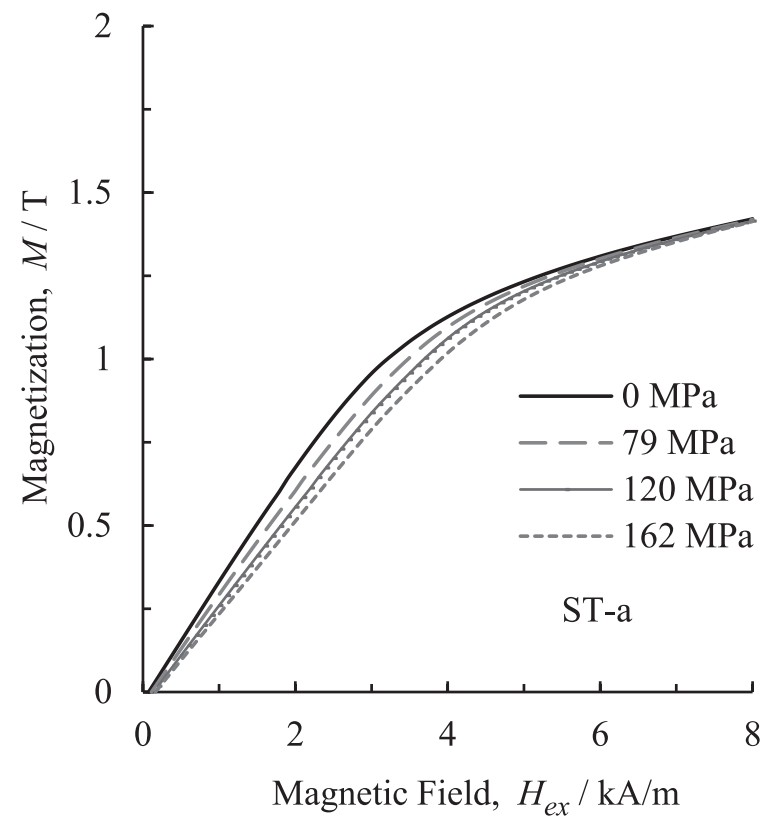

Fig. 5 Magnetization curves of non-oriented electrical steel sheet under compression.

ギーが増して(式 ( 1 ) 参照方), 横向きの磁区が増えることと 磁化過程で更に余分な磁場が要るようになることがその要因 である，応力が高くなるにつれて，前者の寄与分は減ってく るものと推定される。なお，磁化過程における異方性エネル ギーは式(1)のそれと関倸しているが, 式 (1)そのものであ るかどうかは不明である。，そのため，具体的な磁化過程を想 定し見積もる必要がある．3.3 項にて見積もりを行う．方向 性電磁鋼板の場合, 2.3 項で述べたように, 磁区は結晶磁気 異方性が大きいため，最初はロール方向を向いている，そし て, 圧縮応力が印加されて応力が増すとともに横向き磁区が 増していく．無方向性電磁鋼板の場合にも方向性と似た状況 になっているものと考えられる。ナノ結晶の場合には結晶磁 気異方性はない，磁区は，最初はロール方向を向いていて， 
圧縮応力が印加されると応力が比較的小さい段階で，ほとん どすべて横向きの磁区となるものと考えられる。電磁鋼板に おいては, 主に結晶磁気異方性による影響により, 圧縮応力 が印加された際に横向き磁区が増えるのが妨げられる。ナノ 結晶では磁区変更を妨げるのは内部応力による式 ( 1 )の異方 性であろうと推定される

磁化率が一定で, 磁場ゼロにおける磁化がゼロの可逆磁化 過程の場合, 磁化曲線は Fig. 6 のように直線である。図の横 軸は有効磁場であり， $M_{s}$ は飽和磁化である。直線が $M_{s}$ に到 達したときの磁場を $H_{k}$ とすると磁化率 $\chi$ は

$$
\chi=\frac{M_{s}}{H_{k}}
$$

である. 磁化曲線と縦軸間の三角形の面積を $W_{H}$ とすると, それは磁場のした仕事に相当する (式 $(3))$. それを $K_{u}^{*}$ と書 くと, 磁化率は式 $(4)$ となる

$$
\begin{gathered}
W_{H}=\frac{1}{2} M_{s} H_{k}=K_{u}{ }^{*} \\
\chi=\frac{M_{s}{ }^{2}}{2 K_{u}{ }^{*}}
\end{gathered}
$$

さて, Fig. 6 の $W_{H}$ は磁化曲線が同図のように直線の場合, 異方性定数に相当する。 そして $H_{k}$ は異方性磁場 (異方性の 効果と等価な磁場)に相当する. 容易磁化方向に垂直に磁場 を印加した場合で，磁化過程が回転磁化のときには Fig. 6 の ようになることが知られている ${ }^{19)}$. 本研究においては磁区 モデルの 3.3 項で式 $(3)$ が導出される.

また, Fig. 6 においては, 磁化は磁場に比例して増加し, 系のポテンシャルエネルギー(磁場のする仕事)も磁化(磁場) に比例して増加する; 磁化の増加に伴うポテンシャルエネル ギーの増加の仕方も一定となっている.

磁化過程には磁壁移動と回転磁化があるが，磁壁は移動容 易であるので，主な磁化過程は磁壁移動であると考えられ る，圧縮応力下では横向きの磁区が形成されるので，その磁 区で磁壁が移動することを想定している．3.3 項磁区モデル を参照されたい。磁化過程における異方性に分布がない場 合，換言すれば，磁壁移動の際のポテンシャルエネルギーの 増加の仕方(すなわちスロープ)が一定の場合, 磁化率は一定 となる(磁化曲線が直線)

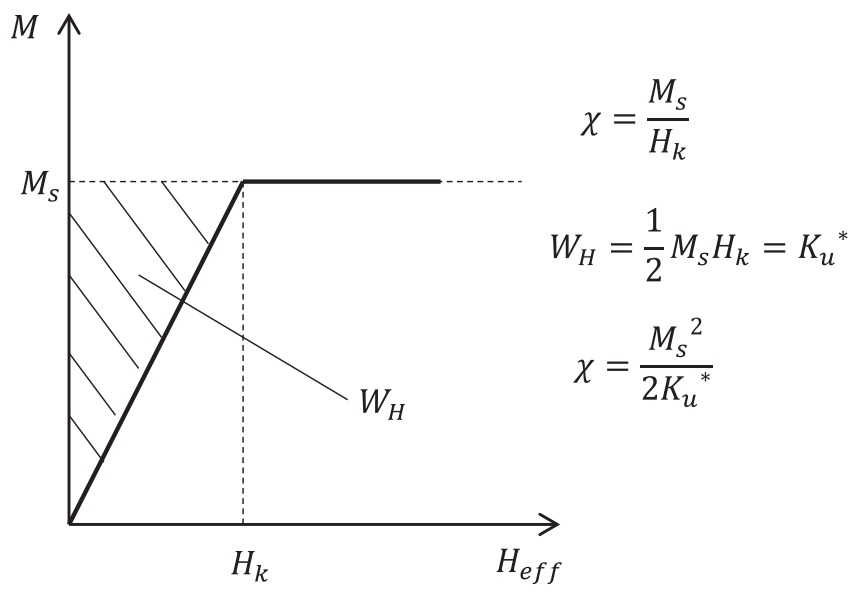

Fig. 6 Schematic diagram of magnetization curve with constant magnetic susceptibility.
ある圧縮応力下での実際の磁化曲線は横軸が有効磁場の場 合には Fig. 7 のようである．直線的に立ち上がり，やがて飽 和していく，立ち上がり部分の平均磁化率は以下のように求 めることができる．OAの大きさを適切に選んで，磁化曲線 $\mathrm{OB}$ と縦軸間の面積を求める. そしてその面積と等しい三角 形を $\mathrm{OAB}^{\prime}$ とすれば， $\mathrm{OB}^{\prime}$ の傾きが平均磁化率になる。 そし て, 三角形 $\mathrm{OAB}$ 'の面積から, 三角形 $\mathrm{OA}^{\prime} \mathrm{B}$ ”の面積を算出す る. 三角形 OA'B”の面積が, その圧縮応力下での磁化過程 における異方性エネルギー $K_{u}{ }^{*}$ であると見なすことができ る. 本研究ではこのようにして, 磁化曲線から磁化過程での エネルギーを求めた。 すなわち, 立ち上がりの磁化過程にお ける異方性エネルギーを評価した，横軸が外部磁場の場合に は三角形 OA’B” に相当する三角形は Fig. 8 のようになる.

さて, Fig. 2 は圧縮応力がゼロと $61 \mathrm{MPa}$ と $124 \mathrm{MPa}$ にお けるナノ結晶材料の磁化曲線である。これらの磁化曲線から Fig. 8 の三角形を容易に想起することができる。ちなみに Fe574の $M_{s}$ は $1.77 \mathrm{~T}$ である。二つの三角形の面積, すなわ ち異方性エネルギーの大きさを比べると倍になっていること が了解される. Fig. 9 に示すように, ナノ結晶材料の場合に おける磁化過程でのエネルギーは応力に比例することが予想 される。

前記した方法にて求めた磁化過程おける異方性エネルギー

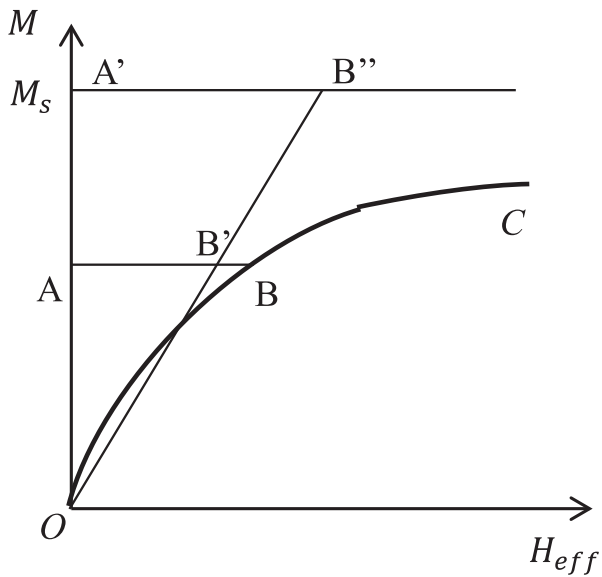

Fig. 7 Magnetization curve and magnetization line with the average magnetic susceptibility.

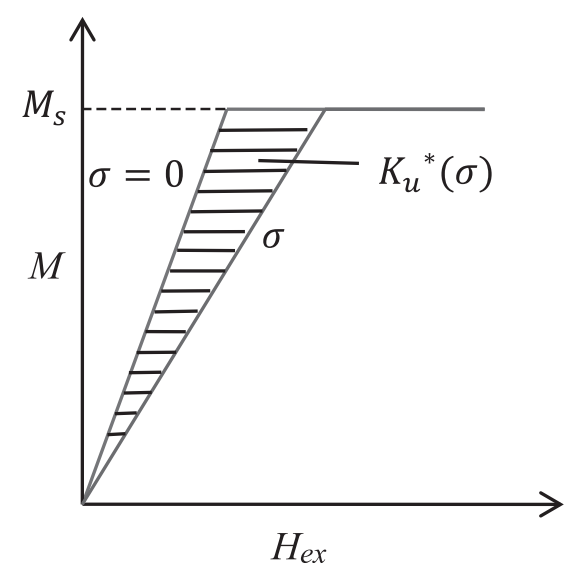

Fig. 8 Schematic diagram of magnetization curve and anisotropy energy. 
の応力依存性をナノ結晶材料の場合には Fig. 9 に, 電磁鋼板 でのそれを Fig. 10 に示す. Fig. 7 における OAの大きさは適 切に設定する必要がある。 ここでは応力 $100 \mathrm{MPa}$ 付近にお ける磁化曲線において, 直線からのずれが $10 \%$ 未満になる ところに磁化の值 (OA の大きさ) を設定した. Fig. 3，4，5 において磁化曲線間の距離が一番大きくなるような位置に相

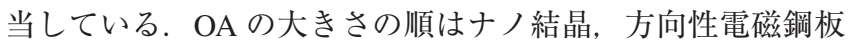
GT, 無方向性電磁鋼板 ST である. ナノ結晶材料では $1.1 \mathrm{~T}$ $\left(M_{s}\right.$ に対して 0.62), 方向性 GTでは $1.0 \mathrm{~T}\left(M_{s}\right.$ に対して 0.49), 無方向性では $0.9 \mathrm{~T}\left(M_{s}\right.$ に対して 0.44)であった. $M_{s}$ に対する OA の大きさは想定している磁化過程が全磁化過程 のうち, どの位の割合を占めているかを示しているとみなせ る. なお, 求まる異方性エネルギーの大きさは, OA の大き さにはあまり依存しないようである. 方向性 GTにおいて,

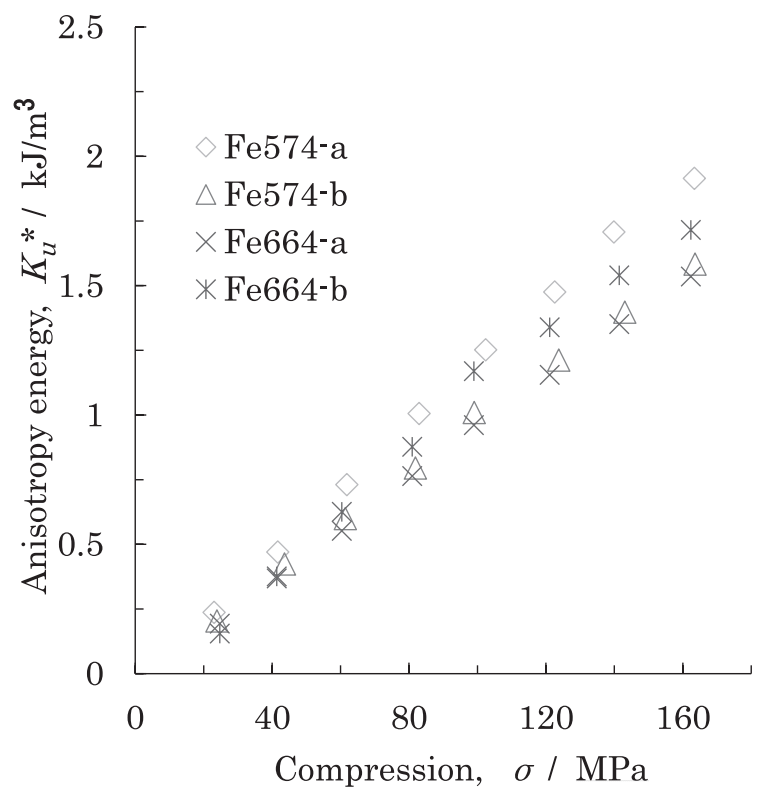

Fig. 9 Anisotropy energy of nanocrystalline alloys under compression.

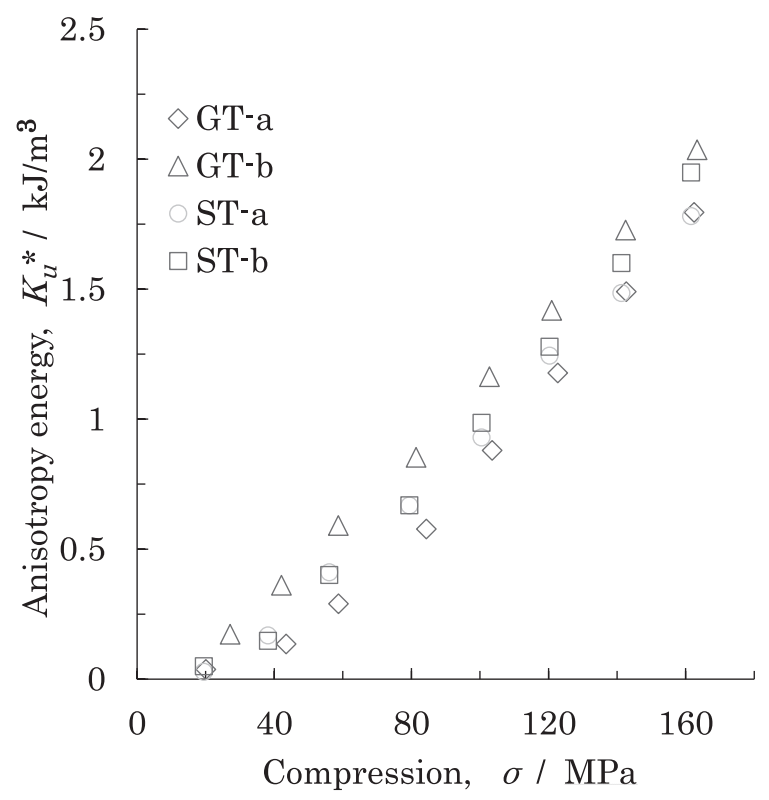

Fig. 10 Anisotropy energy of electrical steel sheets under compression.
OAの大きさを $10 \%$ 変えた場合の異方性エネルギーを求めて みたが異方性エネルギーの変化は $1 \%$ 程度であった。

異方性エネルギーは応力に対して直線的な依存性となって いる．電磁鋼板の場合には既に考察したように，応力が高い ところでのデータを見るべきである．応力に対する傾きは磁 歪の值と関係している．両者の関係を定式化するためには具 体的な磁化過程を想定する必要がある.

磁歪を $10 \mathrm{ppm}$, 応力を $100 \mathrm{MPa}$ とすると磁気弾性，すな わち式（1）のエネルギーは $10^{3} \mathrm{~J} / \mathrm{m}^{3}$ であるから，実験で得 られた磁化過程における異方性エネルギーの大きさとしては 妥当な值となっている。次に, 試料がリン青銅板に接着され ていることによる拘束の影響の程度を見積もる。磁歪を 10 ppm, ヤング率を $200 \mathrm{GPa}$ とすると磁場印加によって発生す る余分なエネルギーは $10 \mathrm{~J} / \mathrm{m}^{3}$ なので影響は小さい. また, 異方性エネルギーを磁化曲線の差から求めていることから, 拘束の影響は更に緩和されているはずである, なお, 同じ理 由により, 反磁場の影響も相殺されている. Fig. 9, Fig. 10 では，同種の材料間でデータに差が生じているが，その主な 要因は試料を接着する際に発生した各試料における内部応力 の違いによるものではないかと考えられる.

\section{3 磁区モデル}

方向性電磁鋼板およびナノ結晶材料の場合を念頭において 磁区モデルを想定する．応力ゼロにおける磁区は，長手方向 (ロール方向, 圧縮応力の印加方向)を磁化方向とする $180^{\circ}$ 磁区であると考えられる，そこで，圧縮応力下での磁区モデ ルを Fig. 11 のように想定した. 圧縮応力下での磁区は一軸

(a)

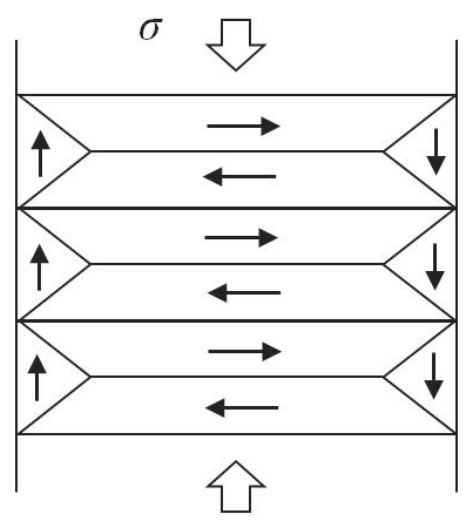

(b)

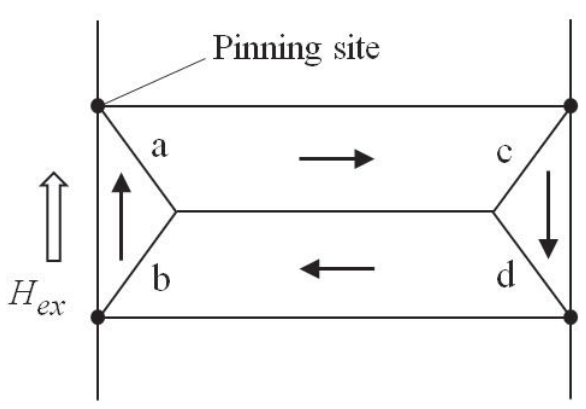

Fig. 11 Magnetic domain model under compression; (a) magnetic domain structure; (b) magnetic domain walls and pinning sites in the one domain block. 
(1)

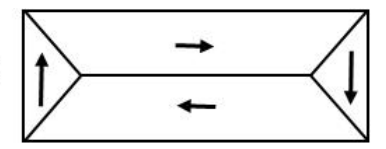

(2)

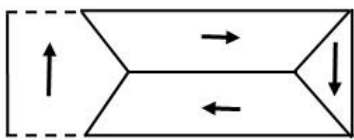

(3)
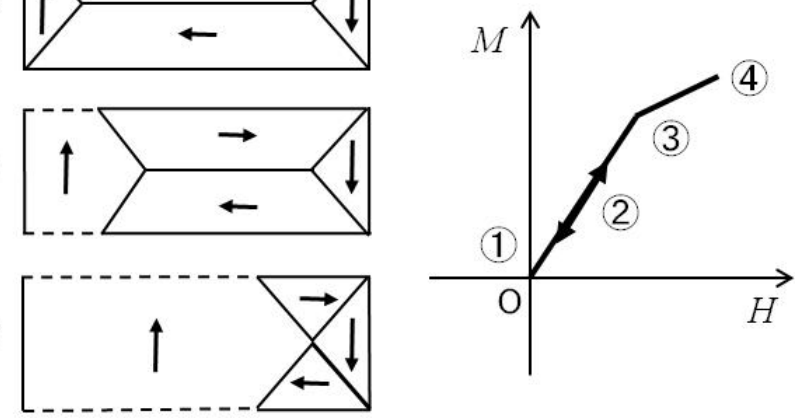

(4)

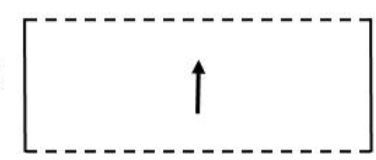

Fig. 12 Magnetic domain and magnetization process.

異方性により圧縮方向に垂直な帯状の磁区 $\left(90^{\circ}\right.$ 方向磁区) 分 布となる．試料端には還流磁区 $\left(180^{\circ}\right.$ 方向磁区 $)$ が形成されて いる，ちなみに，方向性電磁鋼板の場合長手方向は 100 方向 であり，それと直交する方向も100 方向である. 磁壁は試料 板面に垂直であるとする(試料は薄いので磁区は 2 次元的に 分布するとしている)。還流磁区と $90^{\circ}$ 方向磁区間の $45^{\circ}$ の磁 壁は $90^{\circ}$ 磁壁である (Fig. 11 (a))。 上向きの磁場印加により $90^{\circ}$ 磁壁 a, b には左側の還流磁区を拡大寸る向きに磁場によ る圧力 $p=M_{s} \times H$ が垂直に働き ${ }^{20)}$, 右側に動く. $90^{\circ}$ 磁壁 $\mathrm{c}$, $\mathrm{d}$ にも同じ向きに圧力 $p$ が働き, 右側の還流磁区を縮小させ ようとするが試料端面に磁壁の端がピン止めされているため 動けない．磁壁 a, b では同様なピン止めを解除する方向に 力が働くため動き出せる (Fig. 11(b)).

この磁区モデルにおける磁化過程と磁化曲線を Fig. 12 に 示す，磁場がゼロのときが1)である，磁化はゼロである，磁 場が上向きにかかると(2)となる(ここでは保磁力の効果は無 視している)。(3)からが回転磁化で飽和(4)に到達する。磁場 を小さくすると可逆的に(1)に戻る。磁区モデルでは磁化率一 定(磁化曲線の(2))を想定している.

(1)における各磁区での，エネルギー状態は以下のようであ る. 方向性電磁鋼板の場合は, $90^{\circ}$ 方向磁区, $180^{\circ}$ 方向磁区 ともに 100 方向を向いている. 磁化は結晶磁気異方性により 100 方向にいわば拘束されている。結晶磁気異方性のポテン シャルの谷底にいる。結晶磁気異方性の谷底のレベル（深さ） は同じである。一軸異方性エネルギーは $180^{\circ}$ 方向磁区の方

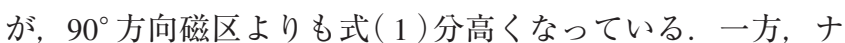
ノ結晶の場合には, 結晶の効果はない; 結晶方位も結晶磁気 異方性も考えなくてよい，一軸異方性エネルギーは方向性電 磁鋼板の場合と同じである，さて，(圧縮応力下では)(1)状態 がエネルギー的に最も安定な状態であることに注目すべきで ある．磁場を印加し(2)の途中で磁場をゼロとすると(1)に戻 る. 磁場を印加すると左側の $180^{\circ}$ 方向磁区の体積が増加す るため，その分，エネルギーの高い状態になるからである。

次に, 説明図 Fig. 13 において, $90^{\circ}$ 磁壁 a, b が右側に距 離 $s$ 移動した場合のエネルギーを見積もろう．90方向磁区 の幅を $d$, 試料厚さを $t$ とすると磁壁が $s$ 移動したときの

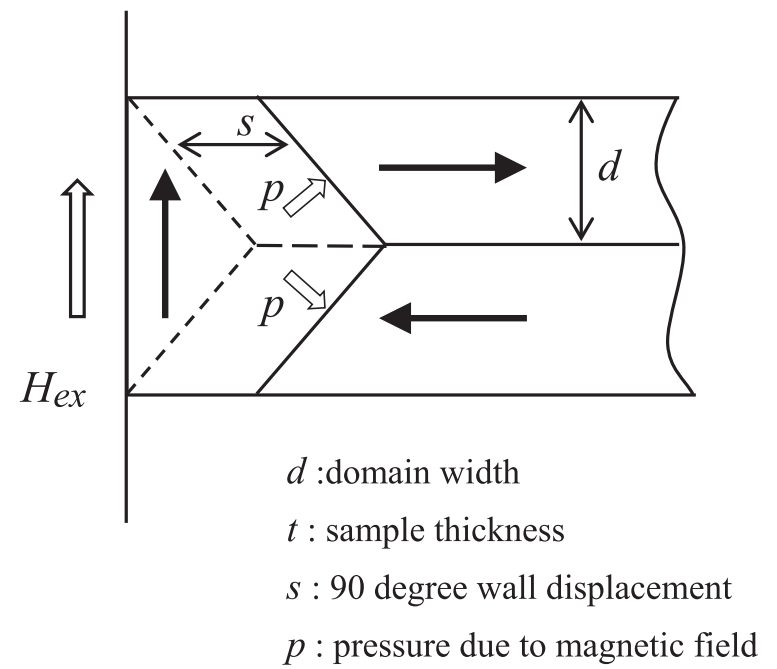

Fig. 13 Movement of 90 degree magnetic domain wall due to magnetic field.

$180^{\circ}$ 方向磁区の体積の増加分 $v$ は $s \times d \times t \times 2$ となる. 圧力 $p$ は磁壁面に垂直に働くので圧力 $p$ の仕事は壁面に働く移動 方向の力と移動距離との積であるが, 圧力はゼロから $p$ まで 変化する $(s=0$ のとき $p=0 ; \mathrm{s}$ のとき $p)$ から, 圧力 $p$ の仕事 は結果としては $1 / 2 \times p \times v$ となる．前述したように $90^{\circ}$ 方向 磁区の異方性エネルギーをゼロ(基準)とすると $180^{\circ}$ 方向磁 区の異方性エネルギーは式 (1)で与えられるから, 異方性工 ネルギーは $K_{u} \times v$ 増加する。 したがって $1 / 2 \times p \times v=K_{u} \times v$ となる. $H_{\sigma}$ をこのモデル $\left(90^{\circ}\right.$ 磁壁移動)での異方性磁場とす ると

$$
\frac{1}{2} M_{s} H_{\sigma}=K_{u}
$$

となる。ちなみに, Fig. 12 で(2)の磁化曲線(直線)を延長し て $M_{s}$ に到達したときの磁場が $H_{\sigma}$ である. 式 $(5)$ の左辺は 磁化曲線に打ける異方性エネルギーである(式 (3)，打よび 文献 10)参照方)。そして, 異方性エネルギーの応力依存性 は式 ( 1 )そのものであることになる.

また, $180^{\circ}$ 方向磁区の体積増加は長手方向の磁歪(縦磁歪) を伴うので, $90^{\circ}$ 磁壁移動における縦磁歪は磁化に比例する ことになる.

\section{4 磁化過程に関する考察}

圧縮応力下での磁化過程が横方向を向いた磁区に打ける 90磁壁移動であるとすれば，式（5），（1）上り，磁化曲線 より求めた磁化過程における異方性エネルギーの応力依存性 に㧍ける傾きは磁区の伸び(磁歪)の値を与えることになる. Table 1 は磁歪の実測值と応力依存性における傾きを対比さ せた表である。なお，磁歪の実測値については 2.1 項， 2.3 項を参照されたい。 また，傾きはFig. 11 に示すような磁区 分布が十分に成り立っていると考えられる，圧縮応力に拀い て直線近似することにより求めた；電磁鋼板の場合には 60 $\mathrm{MPa}$ 付近 $120 \mathrm{MPa}$ 付近, ナノ結晶の場合には $60 \mathrm{MPa}$ 付 近〜100 MPa 付近において直線近似した. GT の場合には傾 きが磁歪の実測值とほほ一致している．ST の場合には合っ ていない.ナノ結晶の場合にも一致していない. 
Table 1 Measured magnetostriction and anisotropy energy line slope.

\begin{tabular}{|c|c|c|}
\hline Sample & $\begin{array}{c}\text { Measured } \\
\text { magnetostriction } \\
\frac{3}{2} \lambda_{s(m e)}(\mathrm{ppm})\end{array}$ & $\begin{array}{c}\text { Line slope } \\
\text { (ppm) }\end{array}$ \\
\hline Fe574-a & 4.3 & 13 \\
\hline Fe574-b & 5.3 & 11 \\
\hline Fe664-a & 3.2 & 11 \\
\hline Fe664-b & 4.3 & 14 \\
\hline GT-a & 12 & 14 \\
\hline GT-b & 13 & 13 \\
\hline ST-a & 6.4 & 13 \\
\hline ST-b & 6.4 & 14 \\
\hline
\end{tabular}

試料厚さが $0.1 \mathrm{~mm}$ よりも厚くないと歪ゲージによる磁歪 の測定值の信頼性はそしくなる ${ }^{12)}$. 本実験の場合には GT, ST の厚さは $0.05 \mathrm{~mm}$ であり, ナノ結晶の場合には $0.018 \mathrm{~mm}$ である.そして, $0.2 \mathrm{~mm}$ 厚さのリン青銅板にも接着されて いるため, 拘束の影響が大きく磁歪の測定值は小さくなって いる．各々の試料の接着積層体 (GT, ST では 4 枚; ナノ結 晶では 7 枚)での磁歪の測定も試みた. GT では 13〜14 ppm, ST では 11〜 12 ppm, ナノ結晶(Fe574)では $14 \mathrm{ppm}$ 程度で あった. Table 1 において磁歪の実測值は，GTでは拘束の影 響で少し小さめの值となっている；STでは結晶粒の向きが ランダムであり, 結晶粒が小さいためと推定されるが, 同じ 厚さの GTよりも大きめな影響となっている；ナノ結晶では かなり大幅な影響となっている，したがって，拘束の影響を 考慮すると, 傾きは磁歪の(本来の)実測值とほぼ一致してい るとみなせると考えられる.

なお, 無方向性電磁鋼板 ST の場合には, 異方性エネル ギーの応力依存性の傾きである磁歪の值が, 試料本来の磁歪 の実測值と一致するとしてよいかについては更なる検討も必 要であると考えられる. 磁区分布は方向性電磁鋼板 GT と類 似であろうと推定されるが, 結晶粒方向がランダムであり結 晶粒サイズも小さいので, 磁区サイズが小さいと予想され, 想定している磁区モデルをそのまま適用できるか等は現状で は不明なためである。

$90^{\circ}$ 磁壁移動における磁歪の挙動は磁化に対して直線的な 変化となるはずである. Fig. 14, 15, 16 はナノ結晶材料, 方向性電磁鋼板 GT, 無方向性電磁鋼板 ST における圧縮応 力下での縦磁歪の挙動である. GT, ST では 0.5 から $1.0 \mathrm{~T}$ 付近で応力が高い場合に, 磁歪挙動は直線的な変化を示して いる.ナノ結晶材料では同じ磁化付近で放物線的になってい て，直線的な傾向が顕著ではない. リン青銅板に 2 次元的に 拘束されている影響(試料が薄い)により，そのような結果と なっているものと考えられる。 よって, 磁歪挙動も磁壁移動 を支持していることになる，また，応力ゼロおよび応力印加

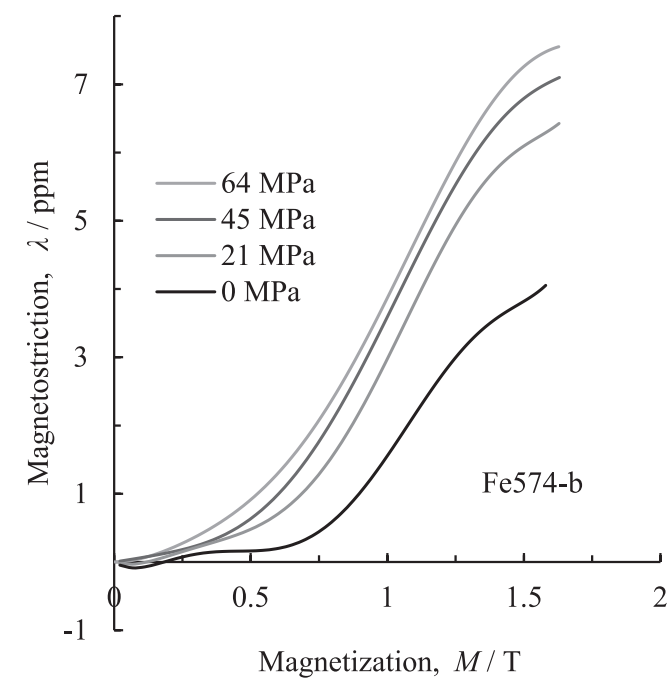

Fig. 14 Longitudinal magnetostriction of nanocrystalline alloy under compression.

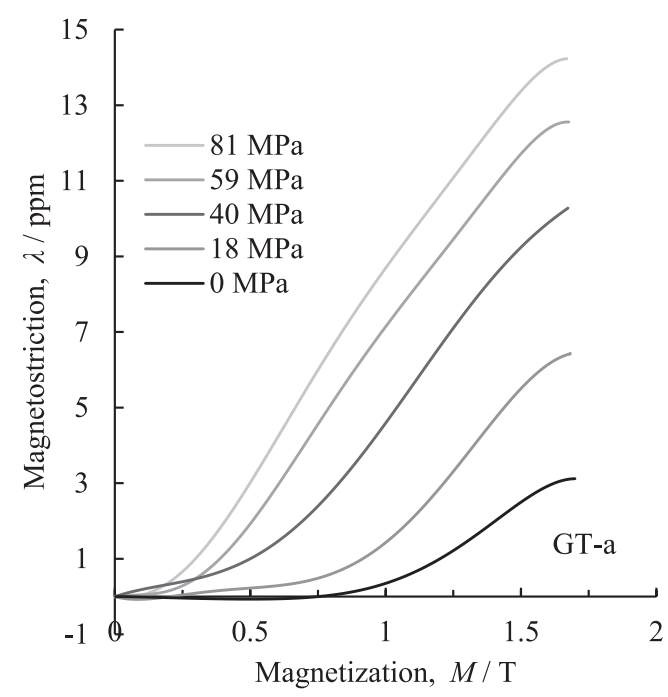

Fig. 15 Longitudinal magnetostriction of oriented electrical steel sheet under compression.

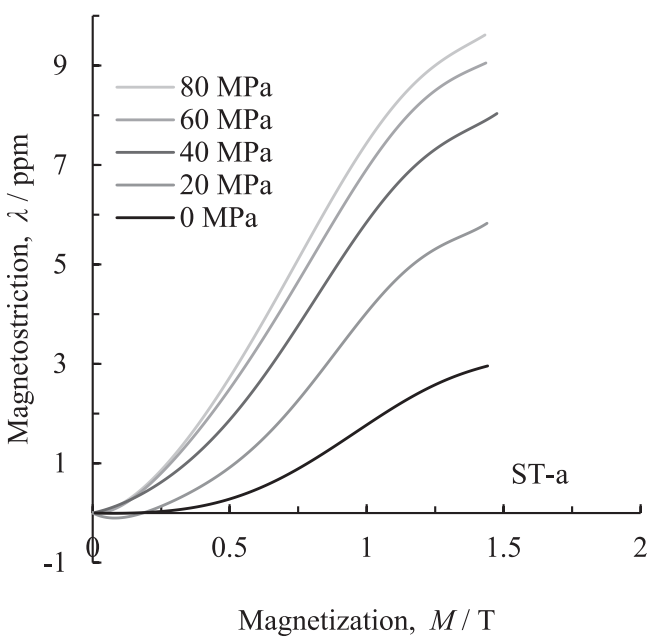

Fig. 16 Longitudinal magnetostriction of non-oriented electrical steel sheet under compression. 
下での縦磁歪の挙動は，以上において述べてきた解析，考察 とも整合している.

\section{5 磁区モデルにおける磁化回転}

Fig. 12 における磁区において, 一軸異方性の方向 (容易磁 化(軸)方向) は横向きである.上向きに(容易軸方向に垂直 に) 磁場を印加すると $90^{\circ}$ 磁壁が右側に移動する。下側の磁 区では磁壁移動に伴い(磁壁が通過すると), 磁化は右まわり に $90^{\circ}$ 回転する.上側の磁区では磁壁移動に伴い, 磁化は左 まわりに $90^{\circ}$ 回転する。このような磁化回転の場合にも，一 斉磁化回転である回転磁化の場合と同じ式 $(3)$ が成り立って いる.この点にも注目すべきであると考える.

\section{6 磁化曲線の応力依存}

以上の議論より, 圧縮応力下での磁化過程における異方性 エネルギーは式 (1)で与えられるから, 磁歪の值がわかれば 求められる. 磁化率と異方性エネルギーは逆数関係(式 (4) 参照方) なので, 応力ゼロでの磁化曲線がわかっていれば, 圧縮応力下での磁化曲線の形を推定することが可能となる. したがって, 圧縮応力下での磁化曲線推定にも本研究の知見 が活かせるものと考えられる. 本研究では異方性には分布が ないとしているが, 分布に関する知見が得られれば, より確 からしい磁化曲線推定も期待される。

\section{4. 結 言}

鉄系軟磁性材料である電磁鋼板, ナノ結晶材料の箔帯軟磁 性材料における一様な応力下での磁化曲線を測定した．正の 磁歪を有する軟磁性材料に圧縮応力を印加すると, 磁化曲線 は磁気弾性による一軸異方性によりその傾きを小さくする. 異方性に分布がないとして応力下における磁化曲線から異方 性エネルギーを求めた，異方性エネルギーの応力依存性は直 線的であった。

圧縮応力下における単純な磁区モデルを想定し, $90^{\circ}$ 磁壁 移動が磁化過程であるとして, 異方性エネルギーの応力依存 性を定式化した。応力依存性の傾きから求まる磁歪の值は, 実測した磁歪の值とほぼ一致していた，そのことから，本研 究では圧縮応力下での主な磁化過程は, 圧縮応力に対して垂 直向きに形成された磁区における $90^{\circ}$ 磁壁移動であると考え てよいという結果を得た。 また, 磁歪も磁壁移動と矛盾しな
い直線的な挙動となっていた。

また，異方性エネルギーの応力依存性を定式化できたこと により, 磁歪の值がわかれば圧縮応力下での磁化過程におけ る異方性エネルギーの大きさが求まる. したがって, 磁化曲 線がどのくらい傾くかを知ることができることから, 本研究 で得られた知見の活用も期待される.

磁区観察による磁区モデルの検証が今後の課題として残さ れている.この分野における本質的な知見とするためにも， モデルのような磁区 (磁壁移動)を直接観察することにより確 証を得ておく必要がある。また，異方性の分布(磁化曲線の 曲がり)に関する検討も今後の課題として残されている.よ り確からしい応力下での磁化曲線の推定につなげるには，分 布に関する検討も欠かせない.

文献

1) K. Yamamoto, E. Shimomura, K. Yamada and T. Sasaki: IEEJ Trans. FM 117-A (1997) 311-316.

2) C. Kaido, N. Hirose, S. Iwata, T. Hayashi and Y. Waki: J. Magn. Soc. Jpn. 34(2010) 140-145.

3) H. Takahara, S. Okumura, S. Kabashima, S. Hayashi and C. Kaido: J. Magn. Soc. Jpn. 35(2011) 291-296.

4) N. Hirose and C. Kaido: J. Magn. Soc. Jpn. 35 (2011) 297-302.

5) Y. Oda, H. Toda, N. Shiga, S. Kasai and T. Hiratani: IEEJ Trans. FM $134(2014)$ 148-153.

6) A. Saito, S. Ueda, S. Murashige and J. N. Nderu: J. Magn. Soc. Jpn. 18 (1994) 437-442.

7) K. Senda, A. Fujta, A. Honda, N. Kuroki and M. Yagi: IEEJ Trans. FM 131 (2011) 884-890.

8) I. Hasif, M. Shimada and T. Kubota: J. Japan Inst. Met. Mater. 82 (2018) 39-43

9) K. Fukawa: J. Japan Inst. Metals 45(1981) 384-388.

10) Y. Suwa, S. Agatsuma, S. Hashi and K. Ishiyama: J. Magn. Soc. Jpn. 34(2010) 342-346.

11) S. Chikazumi: Physics of Ferromagnetism, Vol.2 (Shokabo, Tokyo, 1984) p. 108

12) R. Groessinger, S. Sorta and R. S. Turtelli: J. Electri. Eng. 63 (2012) 9-14

13) T. Kubota, A. Makino and A. Inoue: J. Alloy. Compd. 509S (2011) S416-S419.

14) Z. Akase, S. Aizawa, D. Shindo, P. Sharma and A. Makino: J. Magn. Magn. Mater. 375 (2015) 10-14.

15) S. Chikazumi: Physics of Ferromagnetism, Vol.2 (Shokabo, Tokyo, 1984) pp. 41-43.

16) S. Chikazumi: Physics of Ferromagnetism, Vol.2 (Shokabo, Tokyo, 1984) pp. 125-128.

17) S. Chikazumi: Physics of Ferromagnetism, Vol.2 (Shokabo, Tokyo, 1984) pp. 139-142.

18) R. M. Bozorth: Ferromagnetism (IEEE Press, 1993) pp. 610-613.

19) S. Chikazumi: Physics of Ferromagnetism, Vol.2 (Shokabo, Tokyo, 1984) pp. 250-257.

20) S. Chikazumi: Physics of Ferromagnetism, Vol.2 (Shokabo, Tokyo, 1984) pp. 225-230. 